539.97

$755^{\circ}$ F2dnt 1961
Destruction of

natural fish

habitat is ruining

Montana's fishing streams
N OF NATURAL FISH HABITAT
IONTANA'S FISHING STREAMS

BY

EUGENE B. WELCH

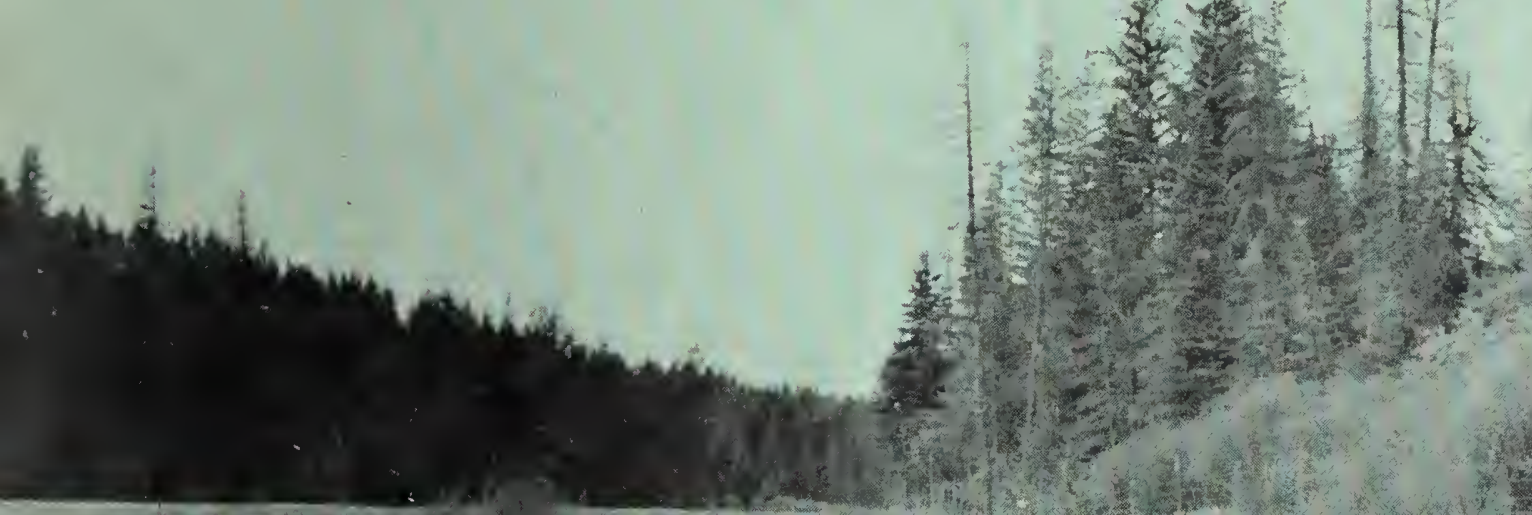

STATE DOCUMENTS COLLECTION

\title{
OCT 331991
}

MONTANA STATE LIBRARY

1515 E. Gth AVE. HELFNA, MONTANA sar 


\section{SEP 161992}

JUL2 21999

Mit: 9003

MONTANA STATE LIBRARY

MAY 152003

30864000745003

Cover Photo: Channel realignment due to highway construction on

Sheep Creek, north of White Sulphur Springs, Montana 
DESTRUCTION OF NATURAL FISH HABITAT IS RUINING MONTANA'S FISHING STREAMS

\author{
Eugene B. Welch \\ Pollution Control Biologist \\ Montana Fish and Game Department \\ November 15, 1961
}

What is happening to Montana's fishing? Is it declining because of increased fishing pressure? Or is it because the Fish and Game Department isn't planting enough fish? These two possibilities can be ruled out because about three-fourths of the fish caught are wild fish and in even the most heavily fished streams, the wild trout populations are underharvested. These facts have prevailed in the face of increased trout stocking。

Records show a sevenfold increase in the catchable trout stocking program over the ten years from 1948 to 1958. With all of these fish being planted it would seem our streams would soon be full of trout and fishing would be getting better and better. Why doesn't this happen? Biologists have shown that "habitat" is the key to good trout fishing. That is, a stream must have adequate cover for trout, preferably brush and undercut banks which are formed by a meandering stream. The stream must have adequate spawning conditions - this means little or no sediment pollution. And adequate foud conditions must prevail - which again means little or no pollution of any form (sediment, organic waste, pesticides or industrial waste). Yes, trout are fussy, and if any of these ingredients for good habitat are missing, a desirable trout fishery, the type that lures anglers from all over the United States to Montana, will also be missing regardless of how many hatchery fish are planted. However, if adequate habitat is available, wild trout can maintain a fishery, in most streams, without stocking. Realizing the extreme importance of Montana's wild trout fishery and the fact that two-thirds of the Montana anglers prefer stream fishing, what is being done to preserve these streams so they will produce trophy trout for future 


\section{Digitized by the Internet Archive in 2016}


generations? Tourists are not attracted by large reservoirs with expanses of exposed mud flats - that is not the kind of trout fishing Montana is famous for. It is the productive trout streams like the Madison, Gallatin, Big Hole, Beaverhead, Yellowstone and Rock Creek (near Missoula), to name a few, that have branded Montana as a famous trout fishing state. The reason they have been productive is because the right kind of habitat has been present.

What is happening to our trout streams? They are slowly being eaten away by legitimate processes carried on under the guise of "progress". Individually the losses do not appear great in most cases, however, grouped they are staggering. What are these processes? They are as follows:

1. Channel realignment by highway construction, railroad construction, individual landowners, municipalities and various federal agencies. Highway construction is the most destructive.

2. Dewatering of the natural streams for irrigation. Without water it is not possible to raise fish. If only the flow is cut for one day - the protection is taken away from the fish revealing it to predators or else the fish dies from increased water temperature and oxygen reduction.

3. Sediment pollution from overgrazing, irrigation waste water, logging or mine wastes. Sediment seals the fate of $f$ ish by decreasing reproduction and the food supply. It does not kill fish directly under natural conditions.

4. Other forms of pollution: industrial waste, pesticides, etc.

5. Stream bank destruction, such as; brush removal, overuse by cattle, diking for flood protection and bank stabilization with car bodies, steel rep rap, etc. These all have the effect of removing the all important cover from the bank which is necessary for trout.

How extensive are the processes of habitat destruction in Montana? How many miles of stream have been affected? To partially answer these questions we might look at highway construction and the impact it has had and will have on several streams in the state. Twenty-four streams, or segments of streams 

XXXX were surveyed during 1961 and were found to have lost at least 64 X\&XXXmiles of their original channel to highway construction/ Meanders were cut off and the water diverted into new, shorter, straightened channels. The water velocity is thus increased and in many cases the stream bank (which has been cleared of vegetation) is eroded causing sedimentation downstream.

What effect does straightening the channel have on the fish population, the water is still there even though the area is reduced? Studies have shown that as much as 94 per cent of the fish six inches long and over can be eliminated from a section of stream that was straightened to follow the highway. Even if the stream is given several years to recover there are still only 4 catchable-size trout where there once were 10. The removal of brush cover (coincident with highway construction) has been shown to decrease or even eliminate a fish population.

South Dakota biologists have shown where there were once 1200 miles of trout streams in the Black Hills, a renowned recreation area, there are now only 160 miles remaining that will support trout. They attribute the major portion of this loss to highway construction and the sediment pollution it produces. The President's Pollution Control Advisory Board considers highway construction as a major cause of sediment pollution and stream destruction.

A pilot study was run by the Fish and Game Department on the Little Big Horn River in which all types of channel alteration were considered. A total of 54 miles ( $45 \%$ of the total length) of original stream channel were lost or altered to the point of being unsuitable for trout.

A few words might be said about stream improvement. Stream improvement devices have not been found to take the place of natural cover. Michigan has been the leader in this field and they have given up widespread use of improve- 


$$
\text { . }
$$


ment structures as too costly with too few dividends. They have gone to improvement of the entire watershed under the theory that a stream depends on a well vegetated watershed in addition to an undisturbed flood plain and without them it is not possible to improve a stream. With a good watershed producing water of sufficient quality and quantity the natural meandering of the stream will create desirable trout habitat. Of course, the stream has to be allowed to meander. Michigan has chosen to treat the real cause rather than the symptom.

Montanans must take action if the valuable trout streams of the state are to be preserved. With proper consideration and direction our trout streams can remain in a natural, productive condition long after highways have come and gone. However, if highways are built at the expense of the trout stream, Montana will soon be holding a "post mortem" similar to that on the now ruined trout streams in the Black Hills of South Dakota. 

The following photos show examples of damage done to Montana trout streams by 

3
$i 5 i+1+3$

$d \leq,+\infty \quad 6$

A I

b. 


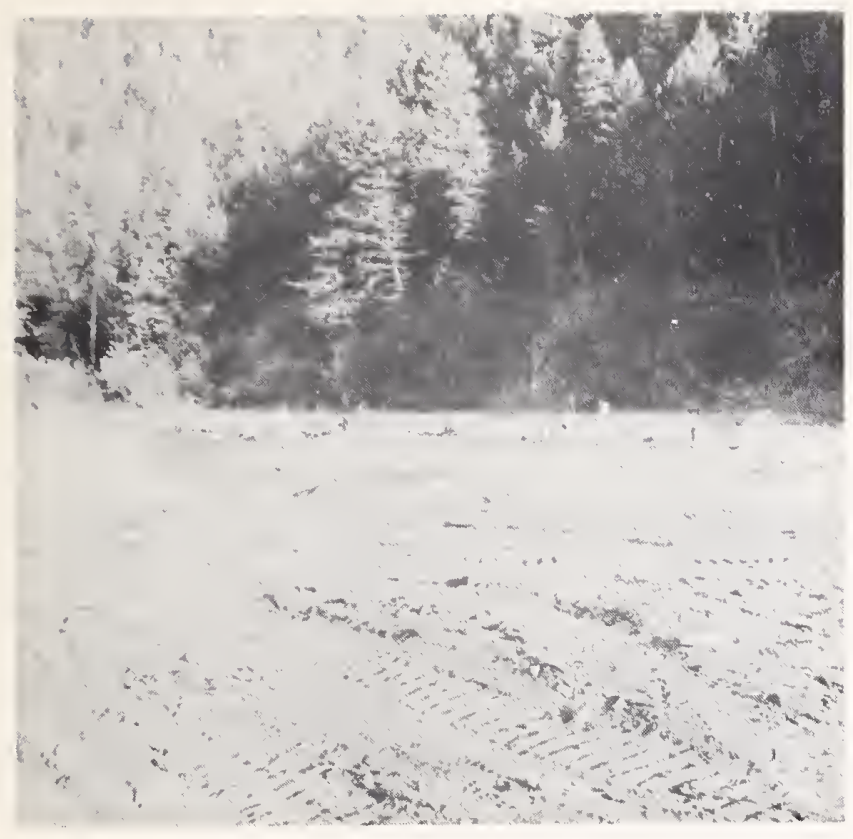

No. 5

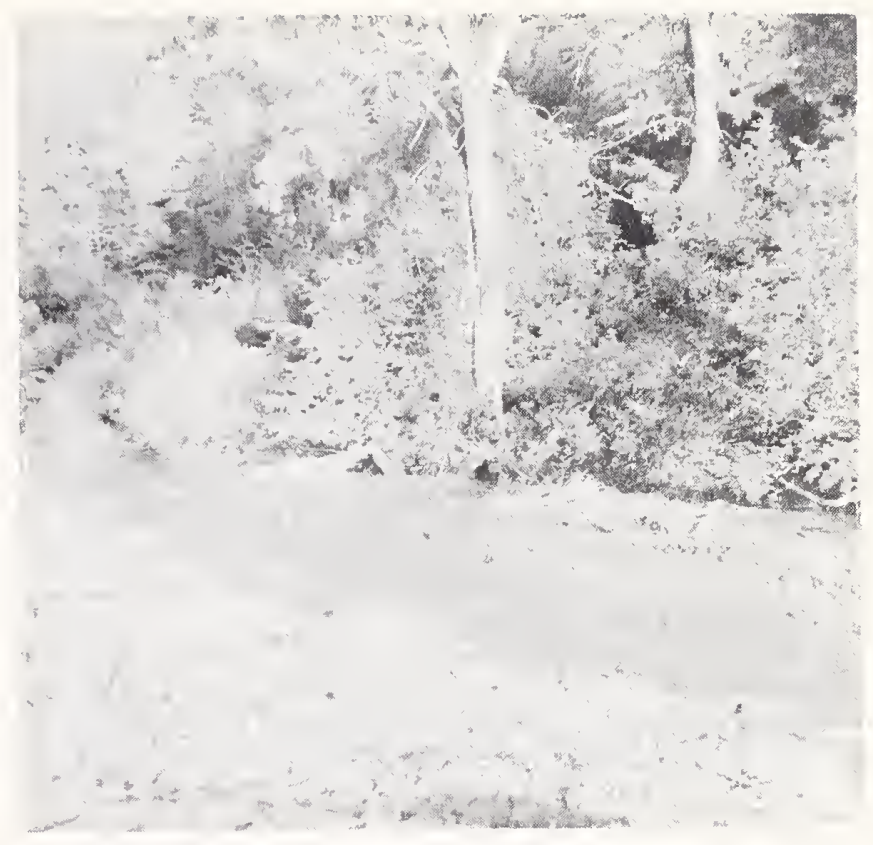

No. 6

Highway construction on Rocky Creek near Bozeman, Montana. Note brush elimination and sedimentation resulting from the construction work.

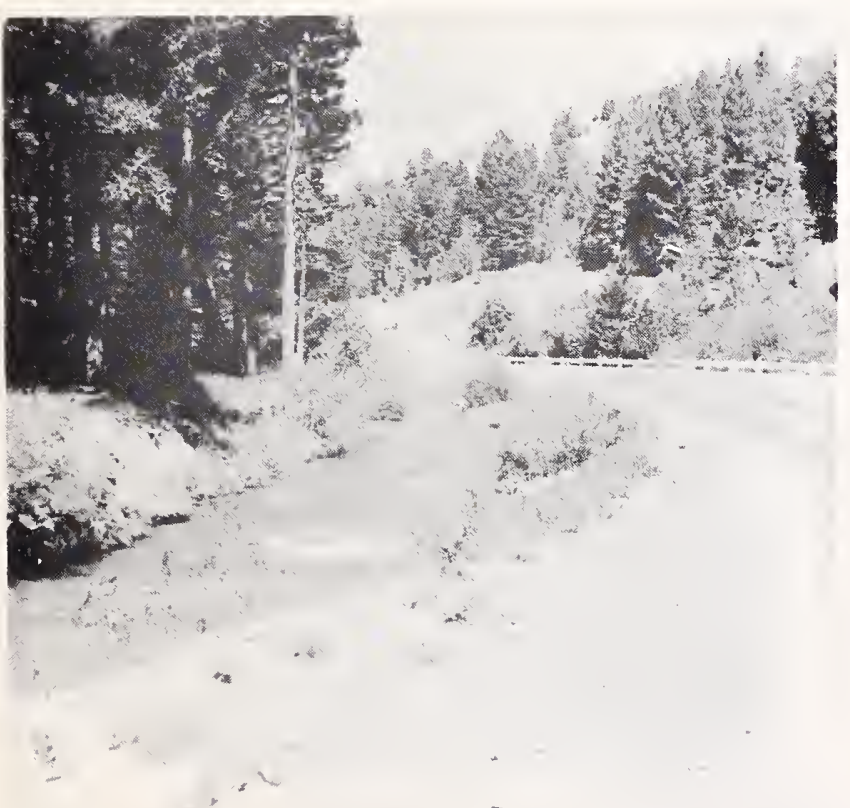

No. 7

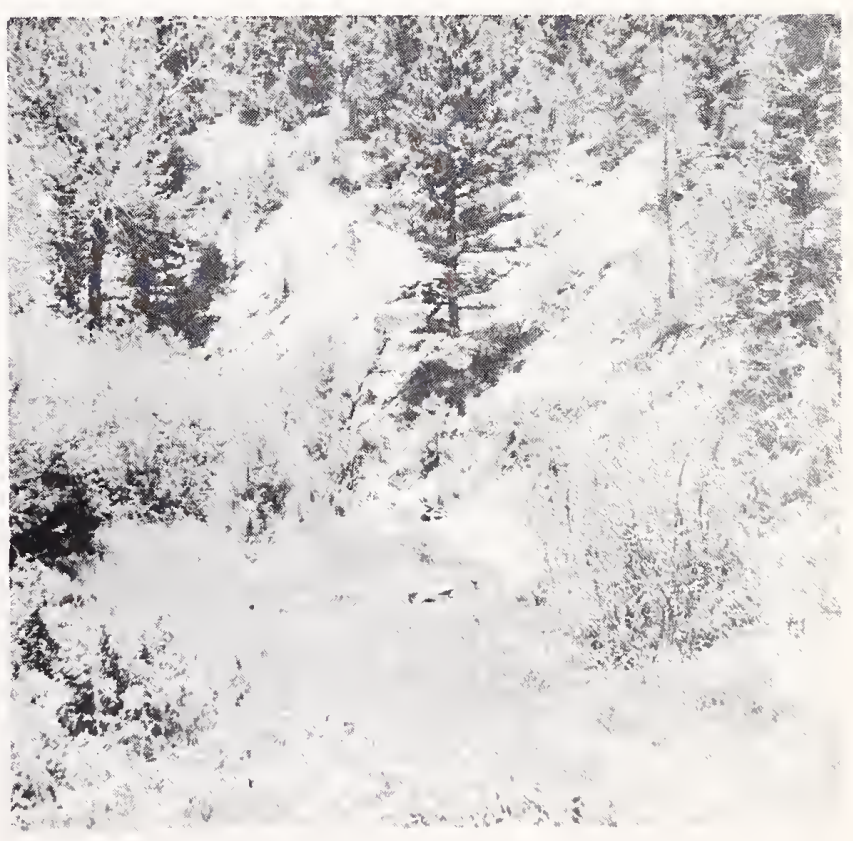

No. 8

The new channel and old channel of a section of Deep Creek near Townsend, Montana. 


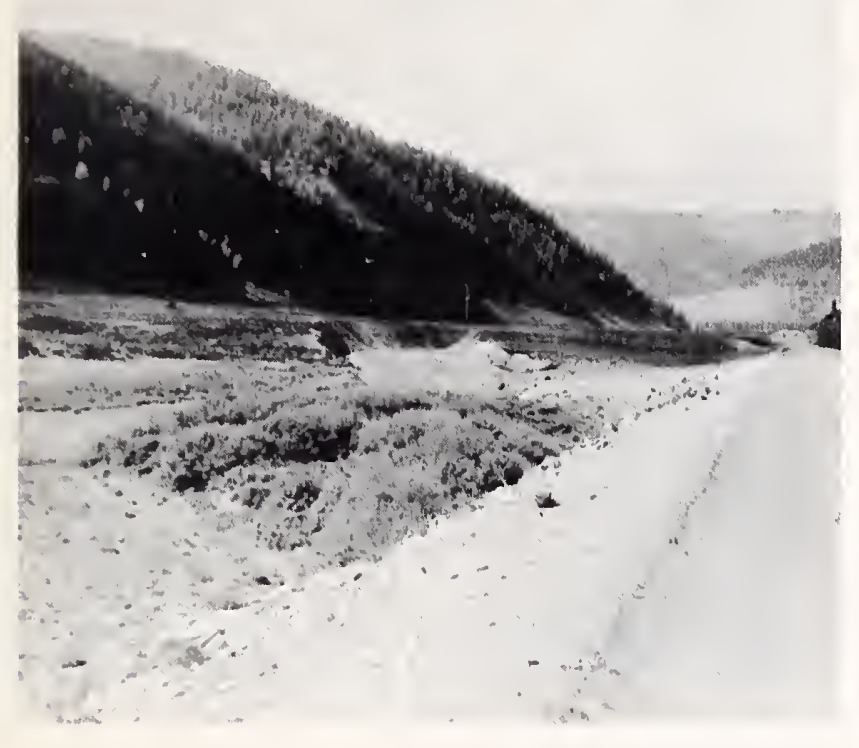

No. 9

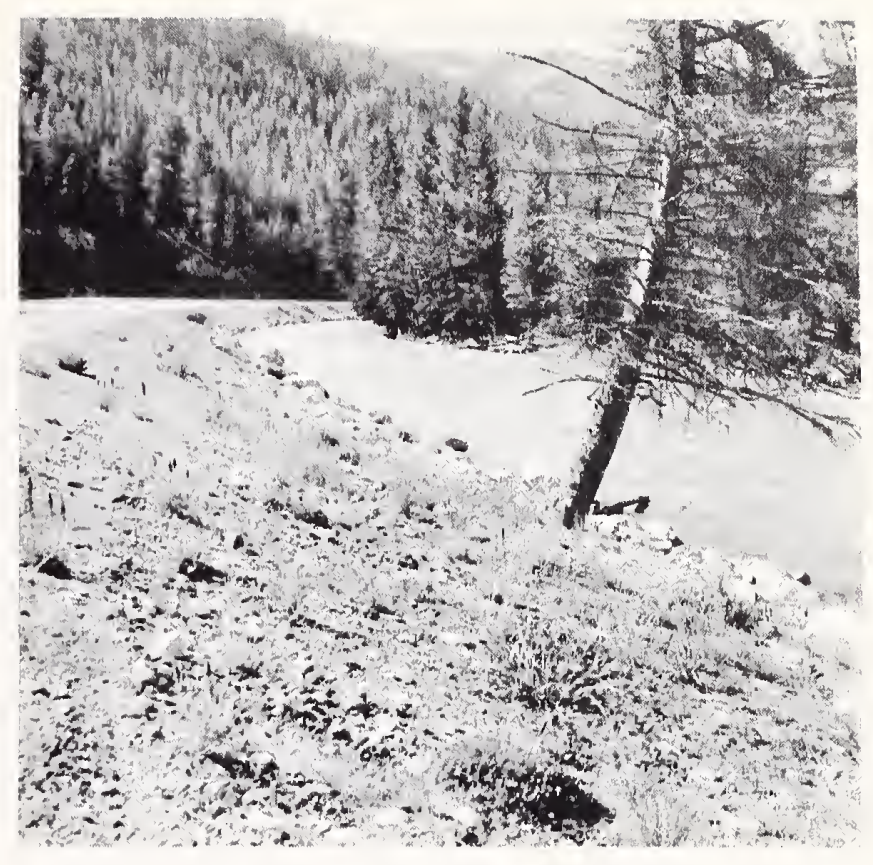

No. 10

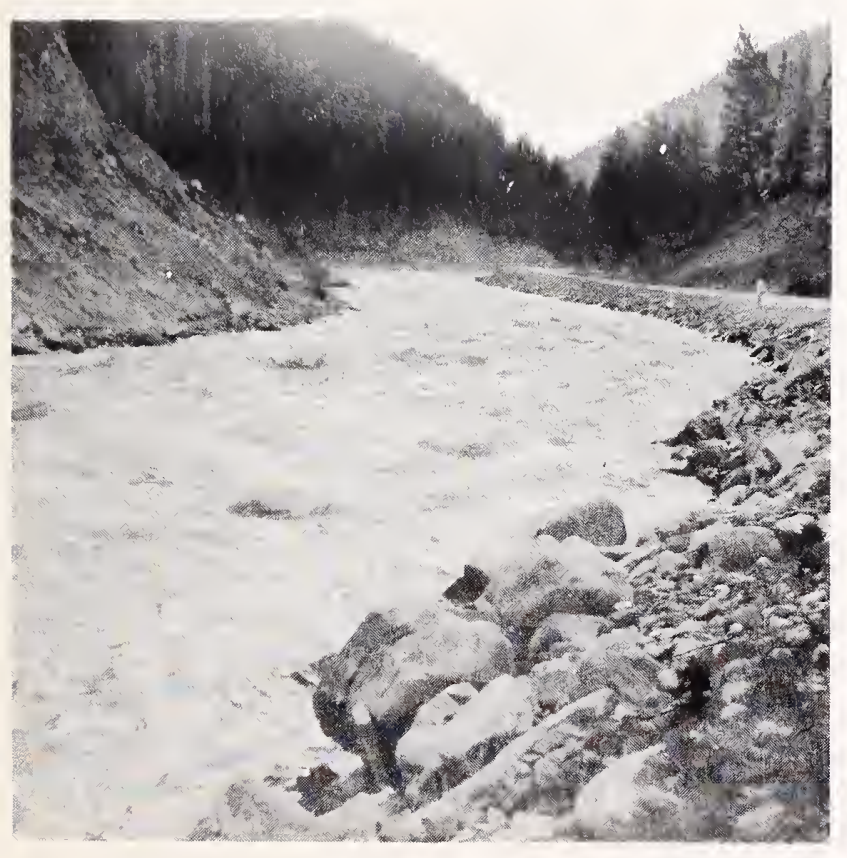

No. 11

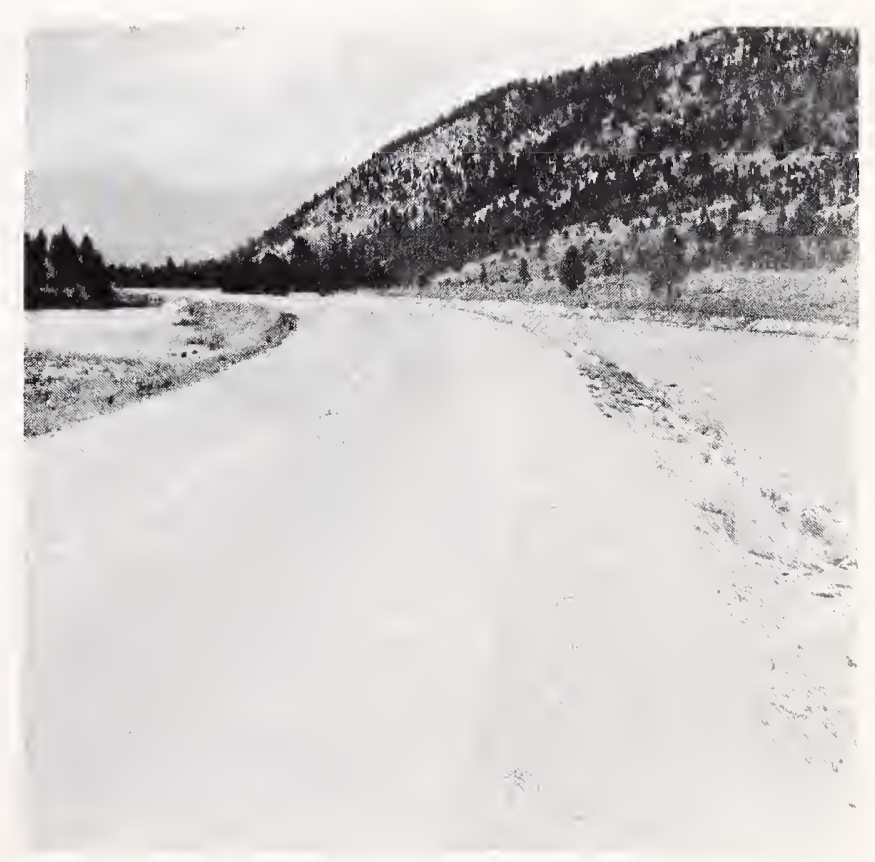

No. 12

Various sections of the West Gallatin River between Gallatin Gateway and Yellowstone Park. Note the flume effect created by the channel changes. 



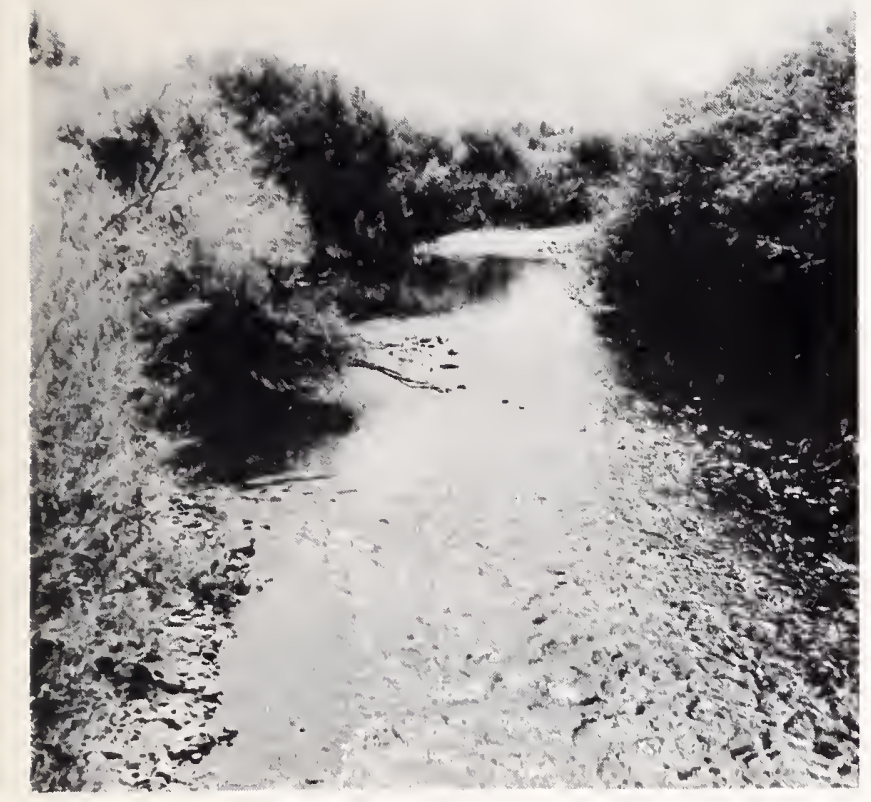

No. 13

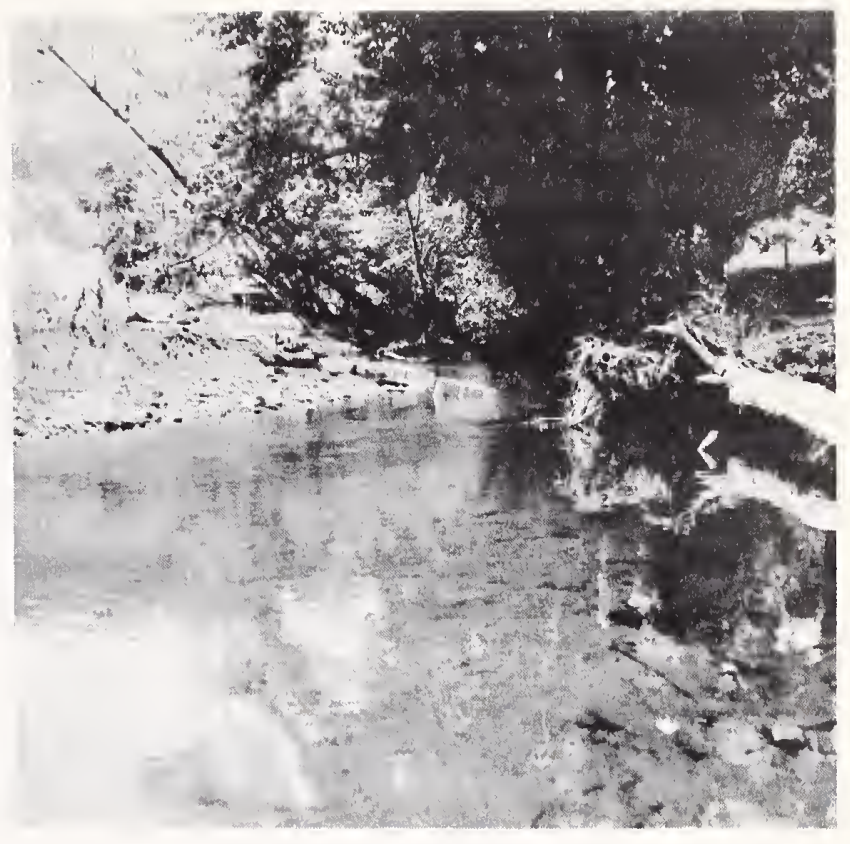

No. 14

Two of six sections on Prickley Pear Creek which were recently electrofished to get pre-highway information on the fish population. These two sections will be altered by Interstate 15 construction.

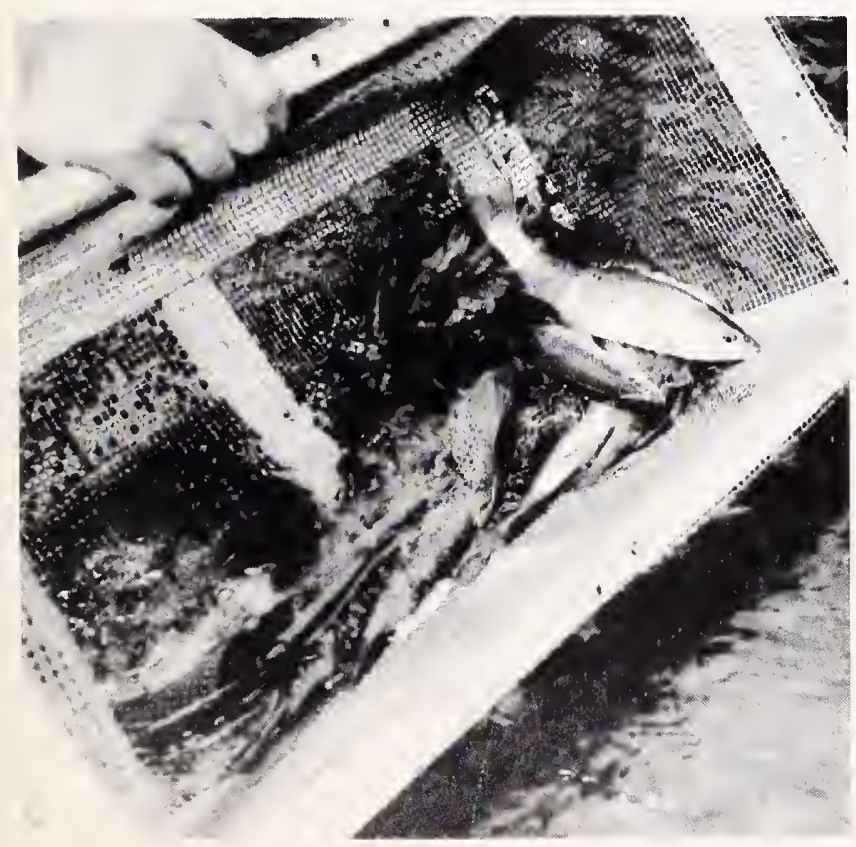

No. 15

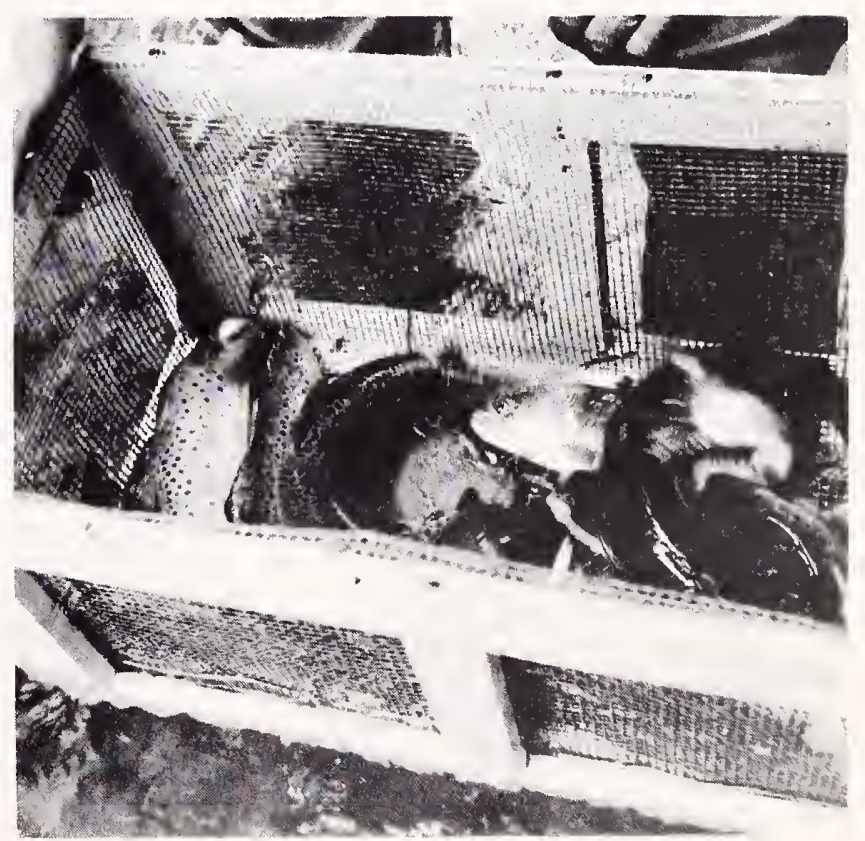

No. 16

Some of the trout taken from these two sections. 

$\left.+4 x^{2}+x^{2}\right)^{2}$

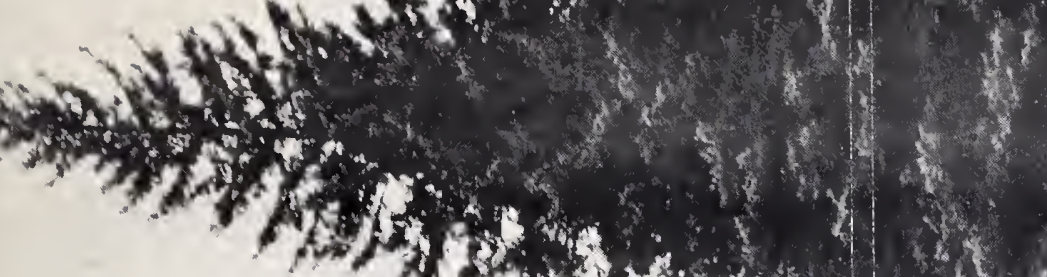
Wro has

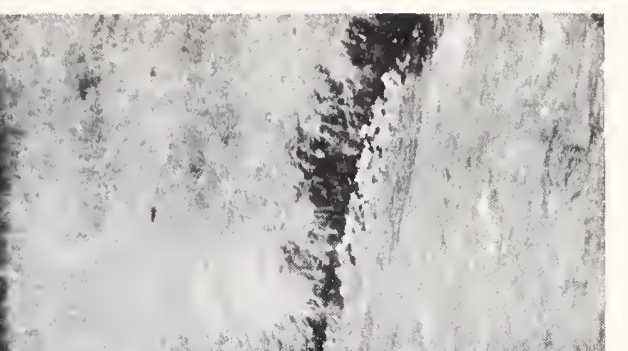

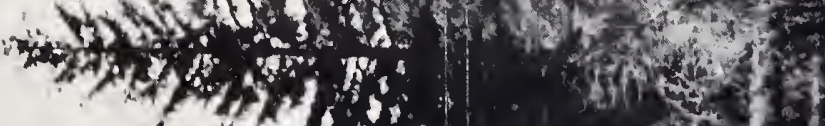

int

(4)
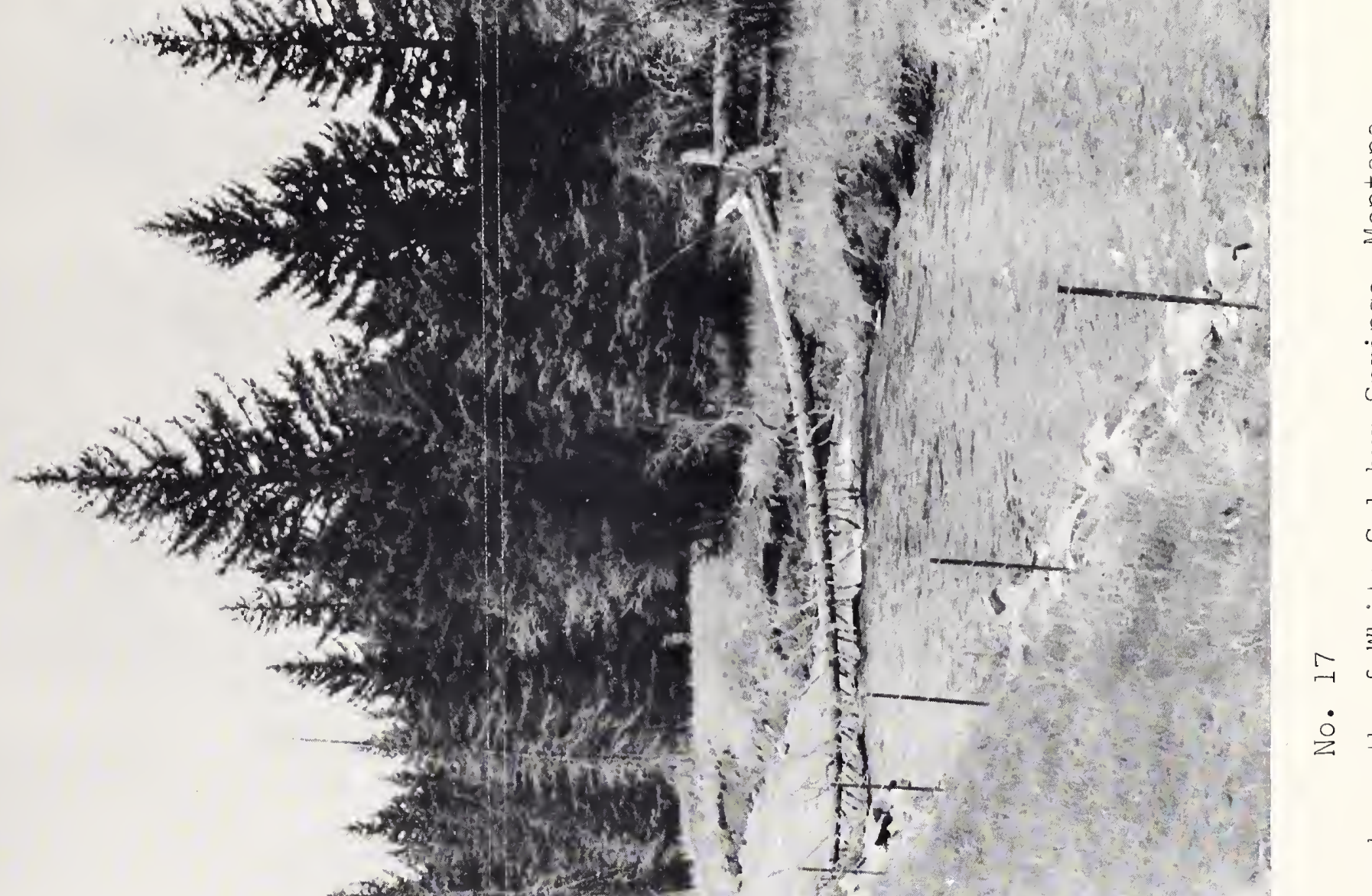

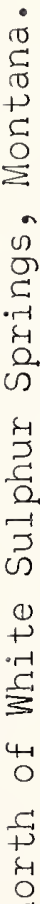

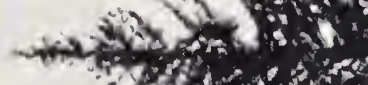

,

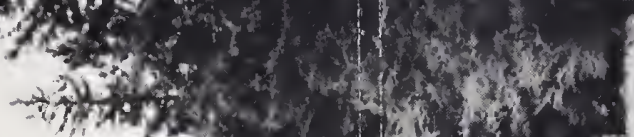
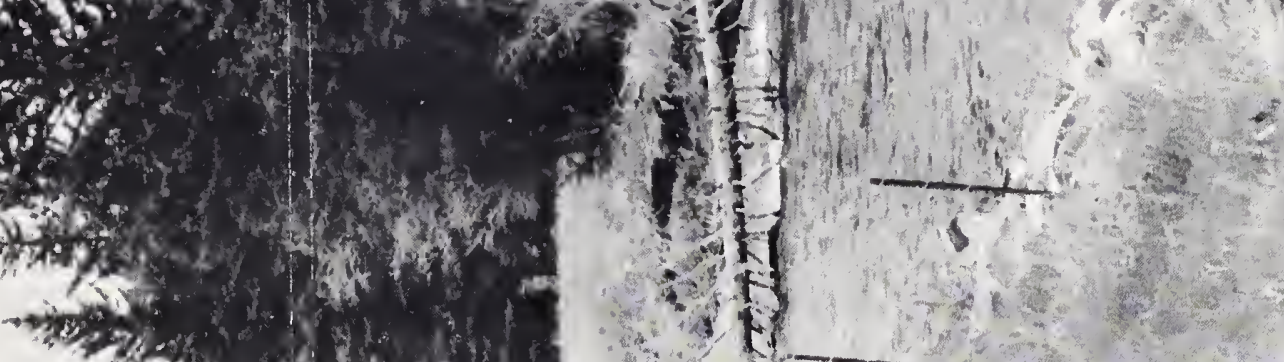

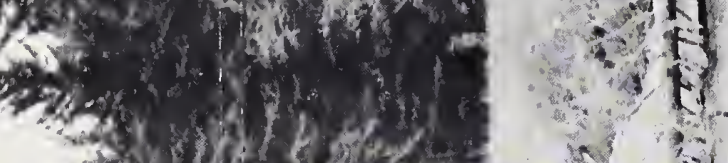

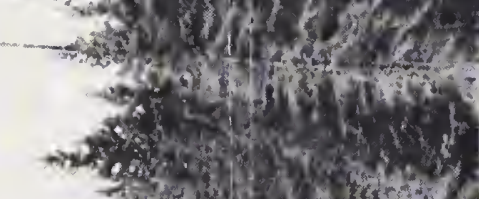

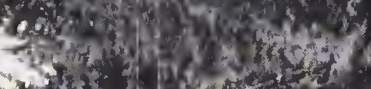

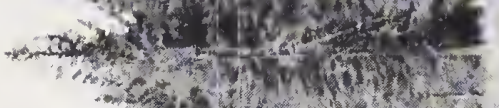

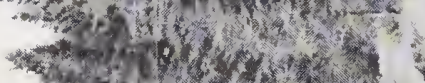

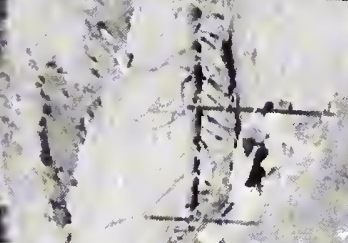

menth

(1)

$\rightarrow$ th $x$.

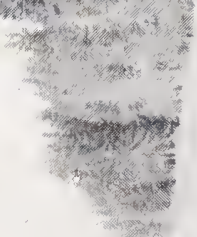

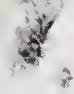


is
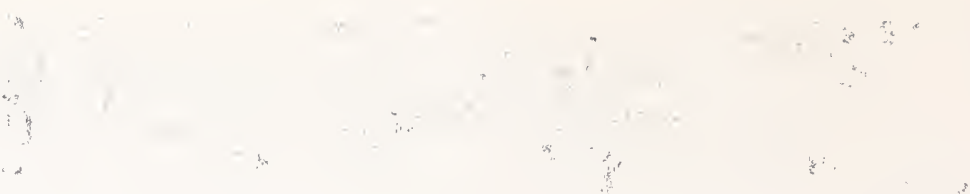

1.

i

$\therefore$

,

1. 


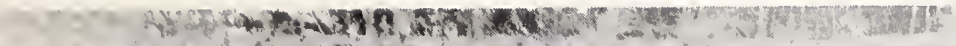

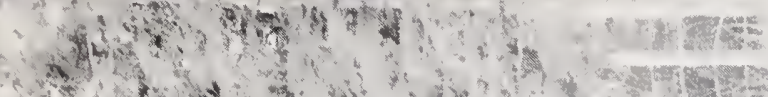
th $13+y$ h $1+x^{2}$

\section{Wha} \%
.

.

,

Whing

mintions

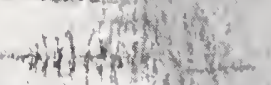
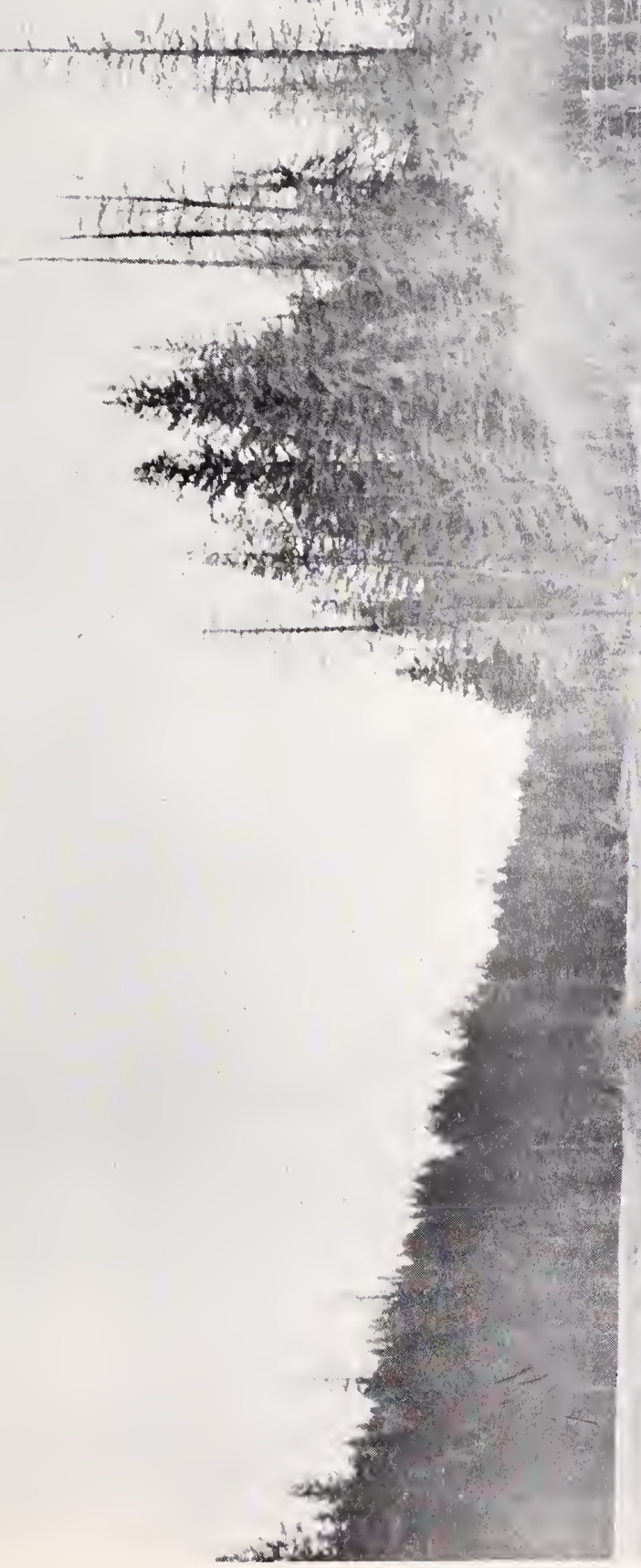

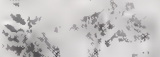
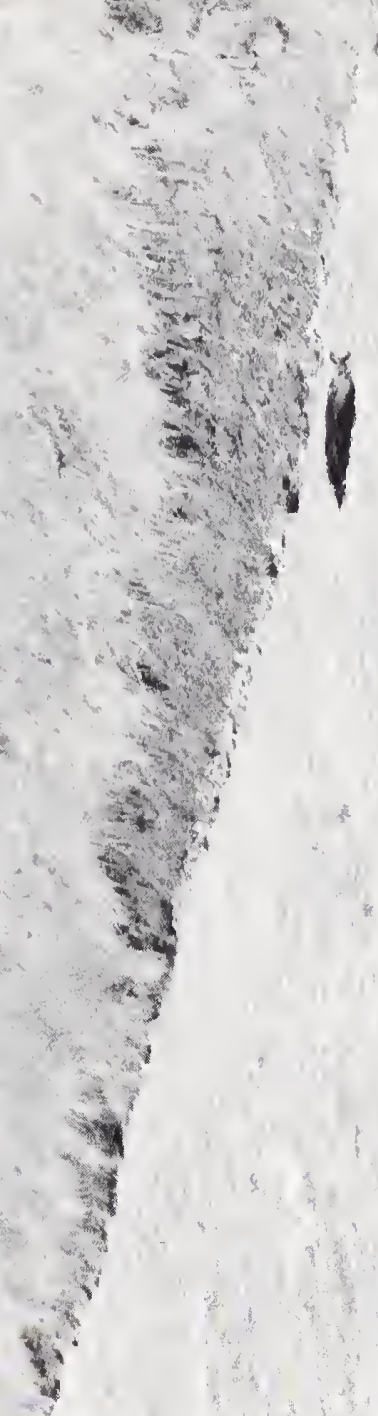

$\underset{-1}{\infty}$

$\dot{0}$
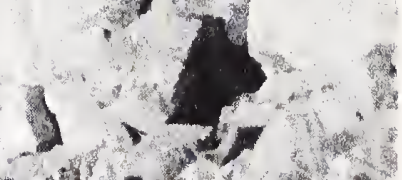

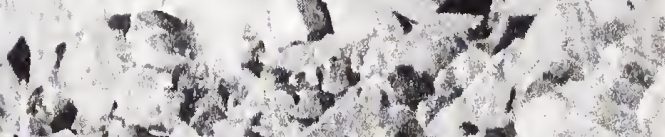

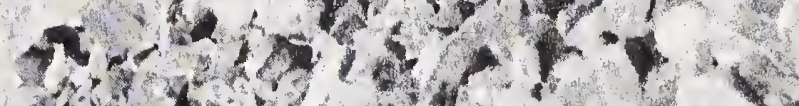
d.

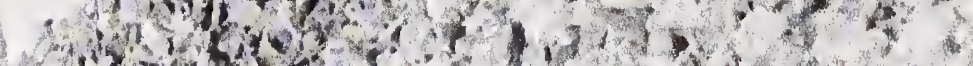

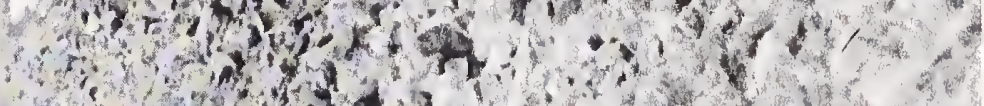

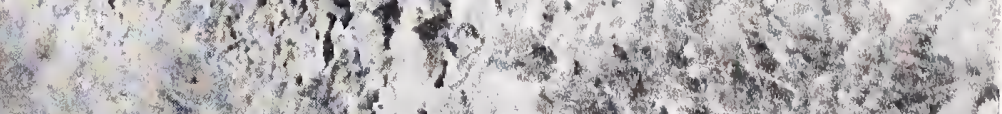

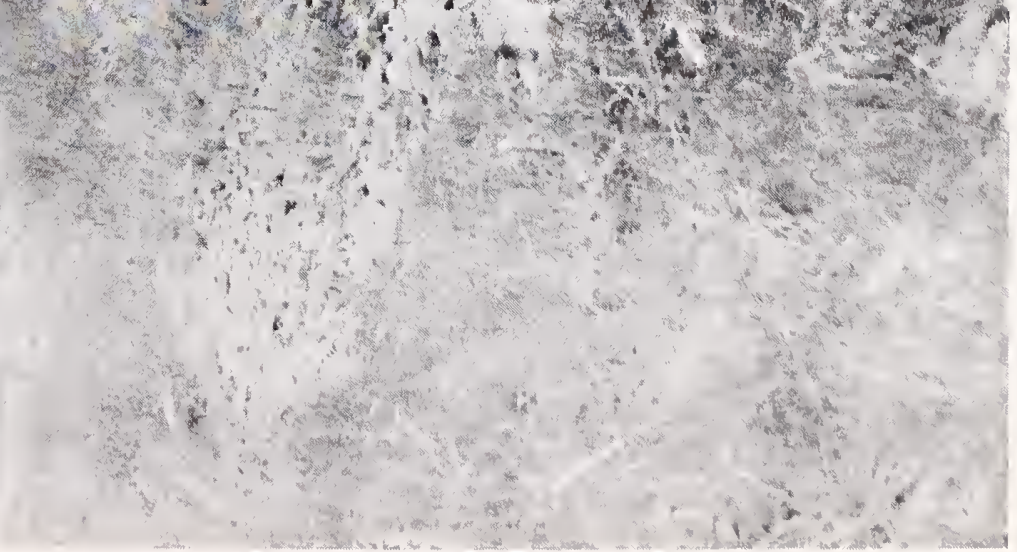





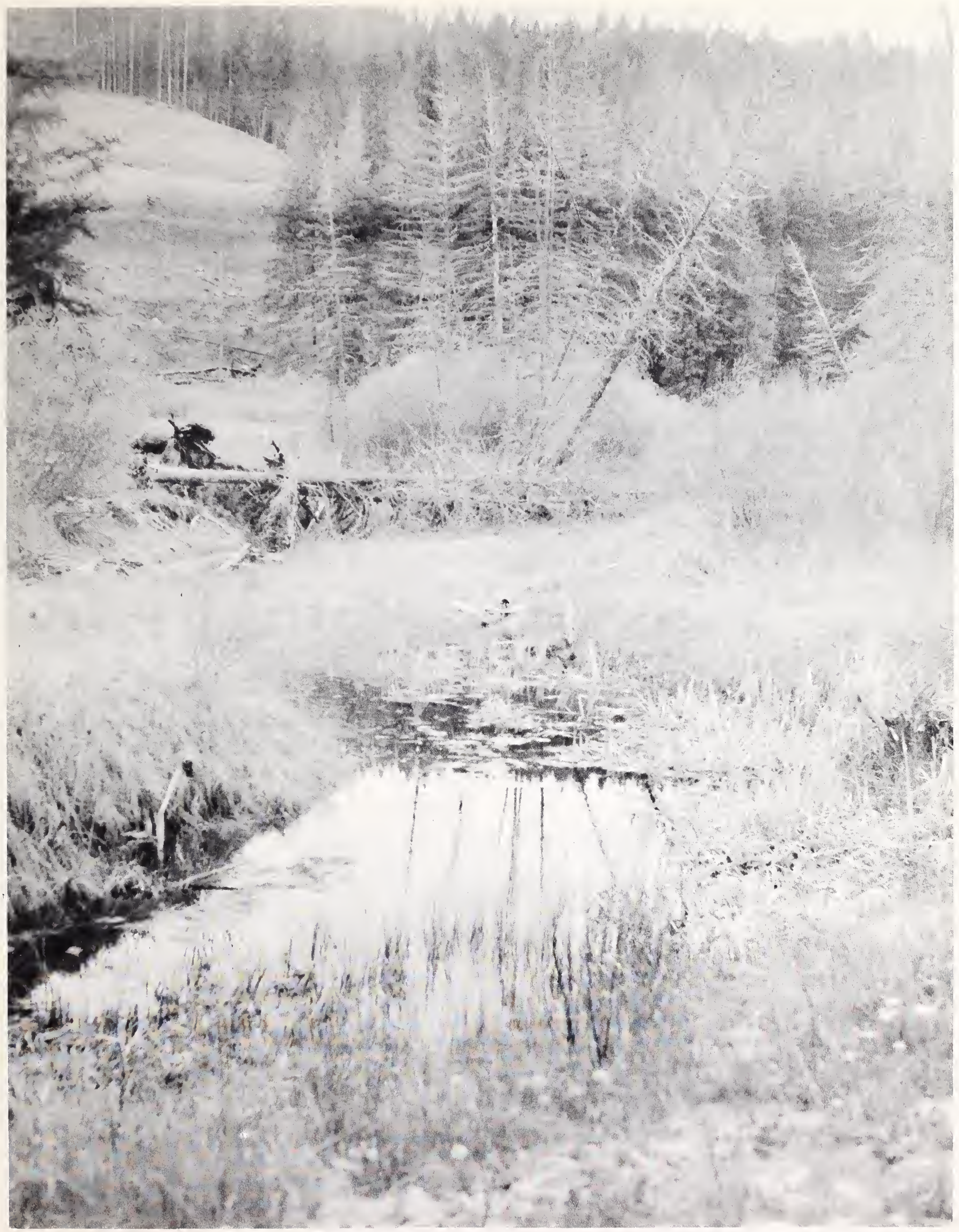

No. 19

A section of natural stream channel on Sheep Creek which was eliminated by the construction of Highway 89. Note desirable overhanging brush, meandering nature and well vegetated banks which is in direct contrast to photo Nos. 17 and 18 from the same area. 



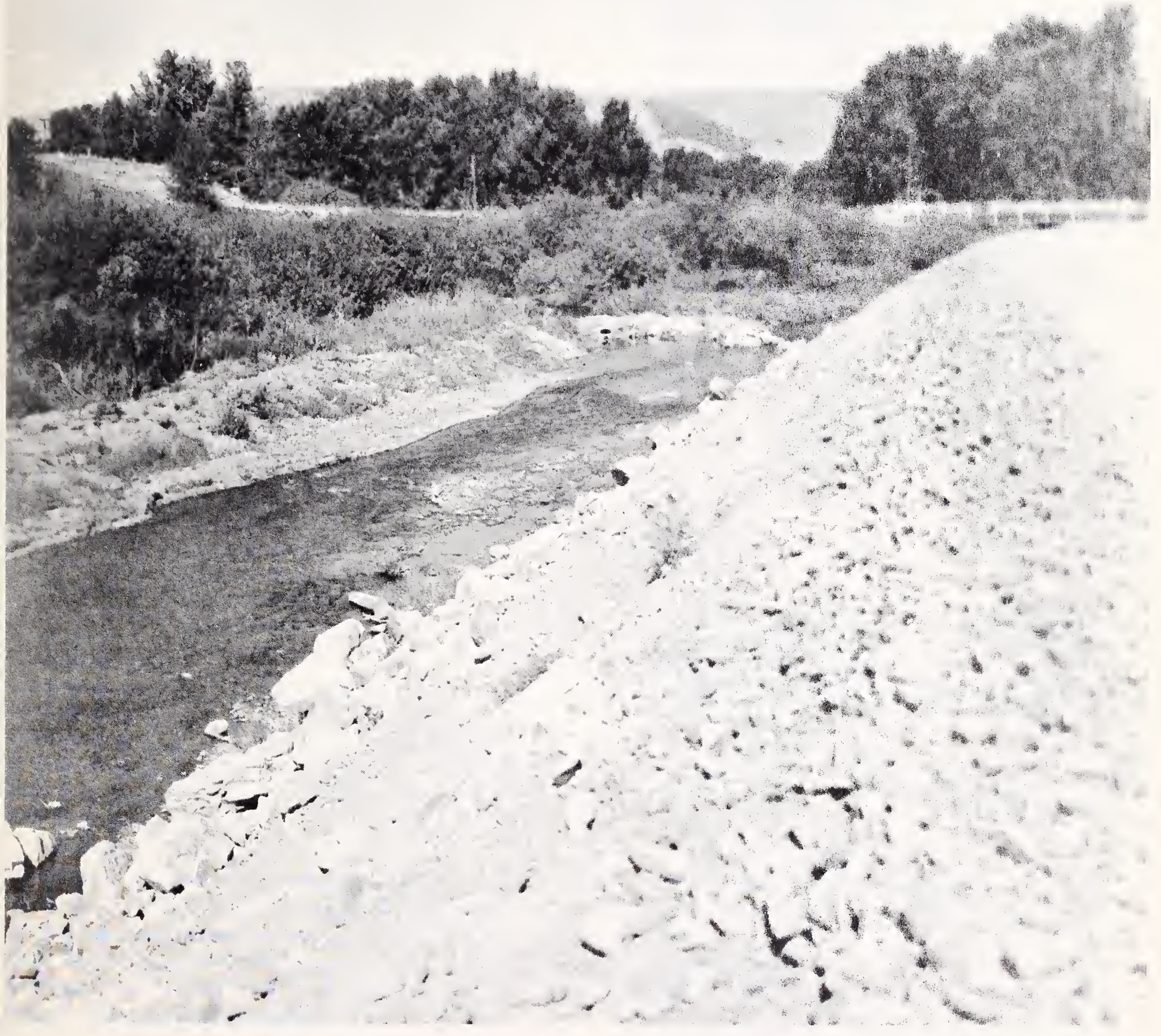

No. 20

A section of realigned channel on Flint Creek above Philipsburg, Montana. 



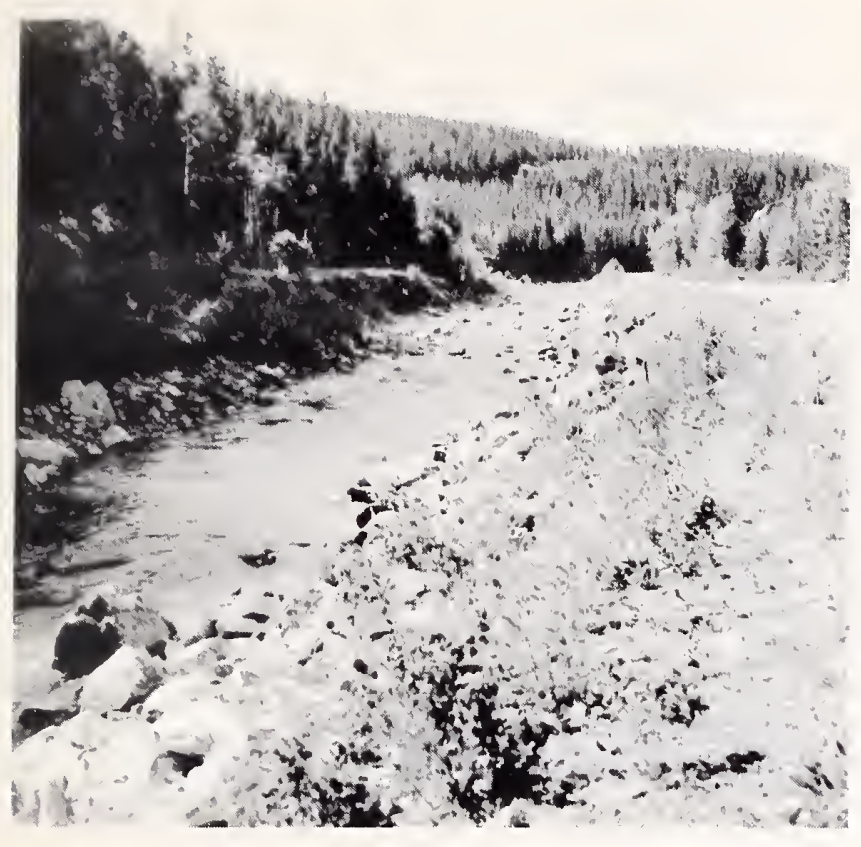

No. 21

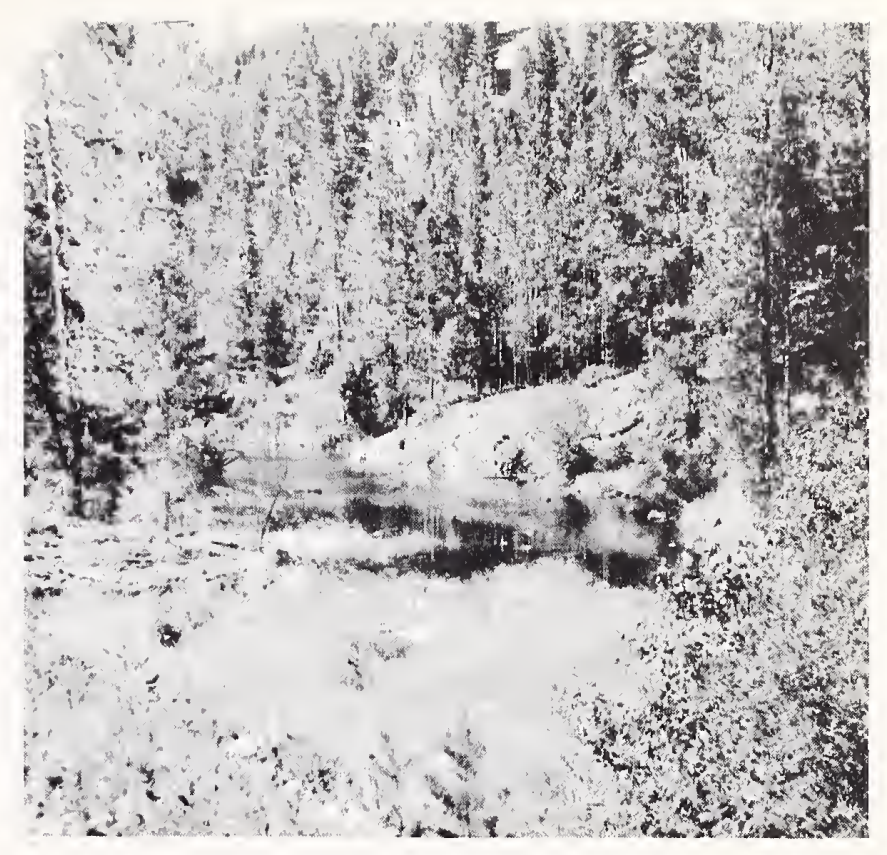

No. 22

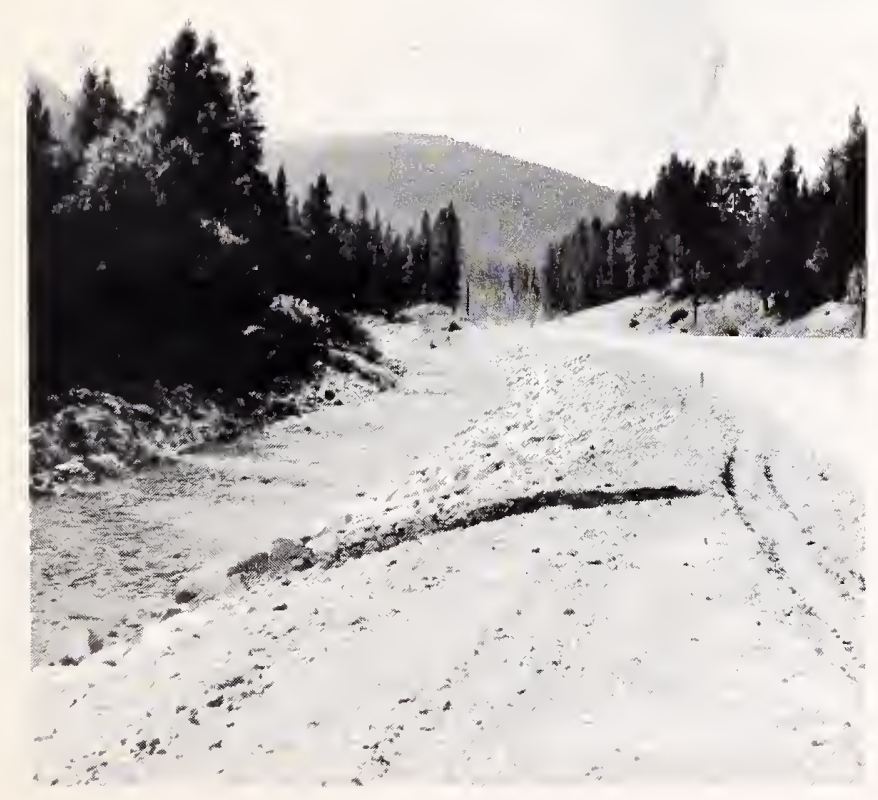

No. 23

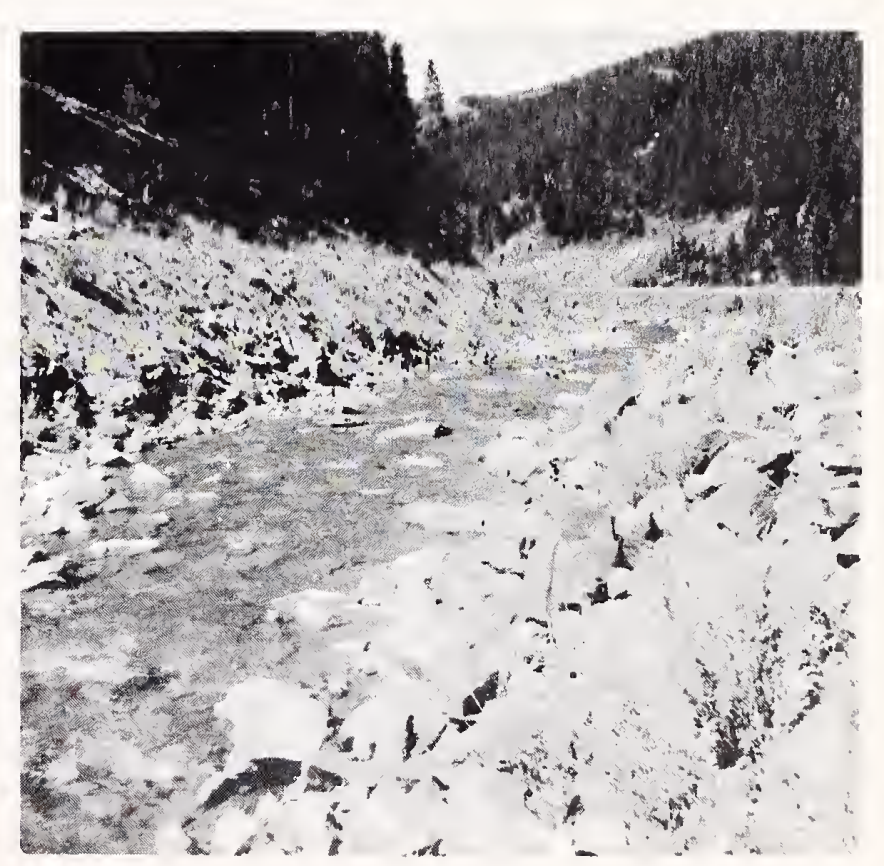

No. 24

Channel realignments along Belt Creek near Neihart, Montana. The channel in No. 21 is what replaced the natural channel in No. 22. 


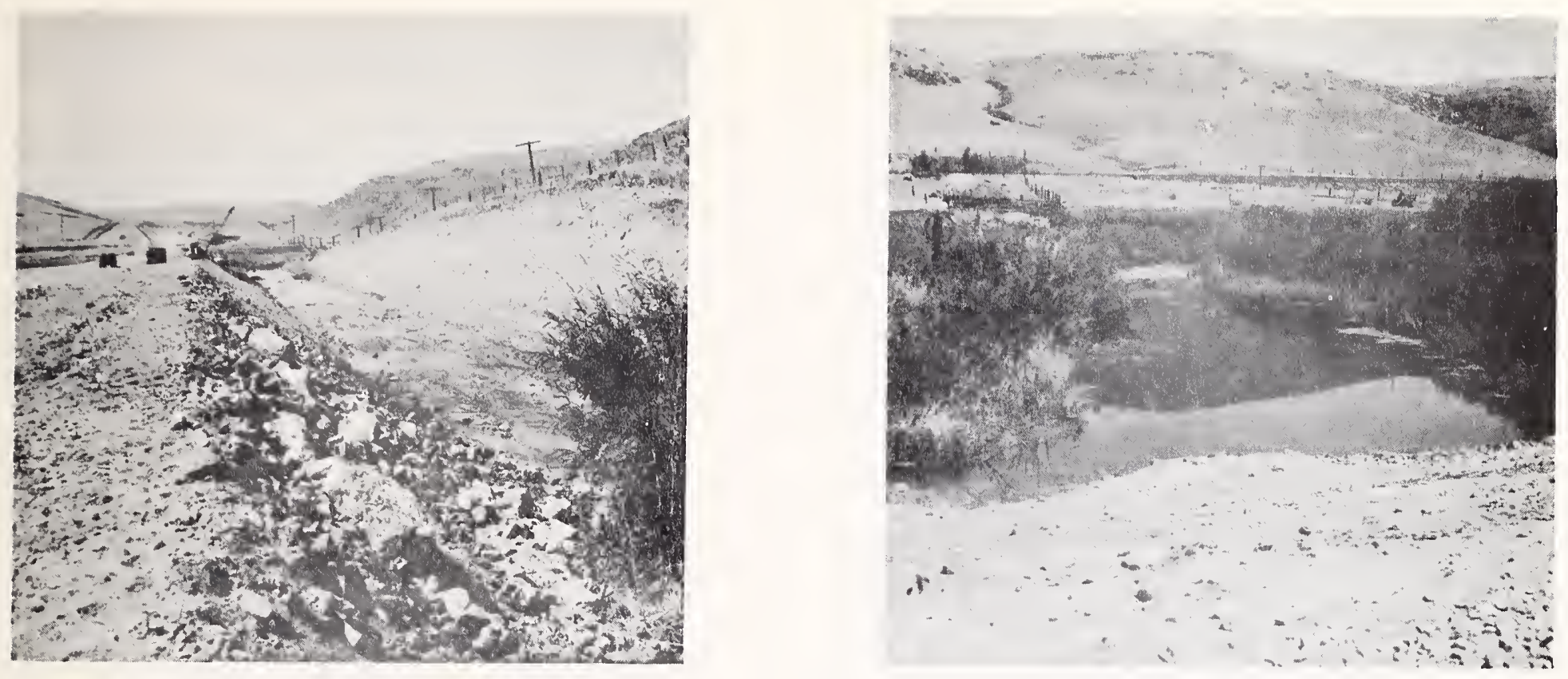

No. 25

No. 26
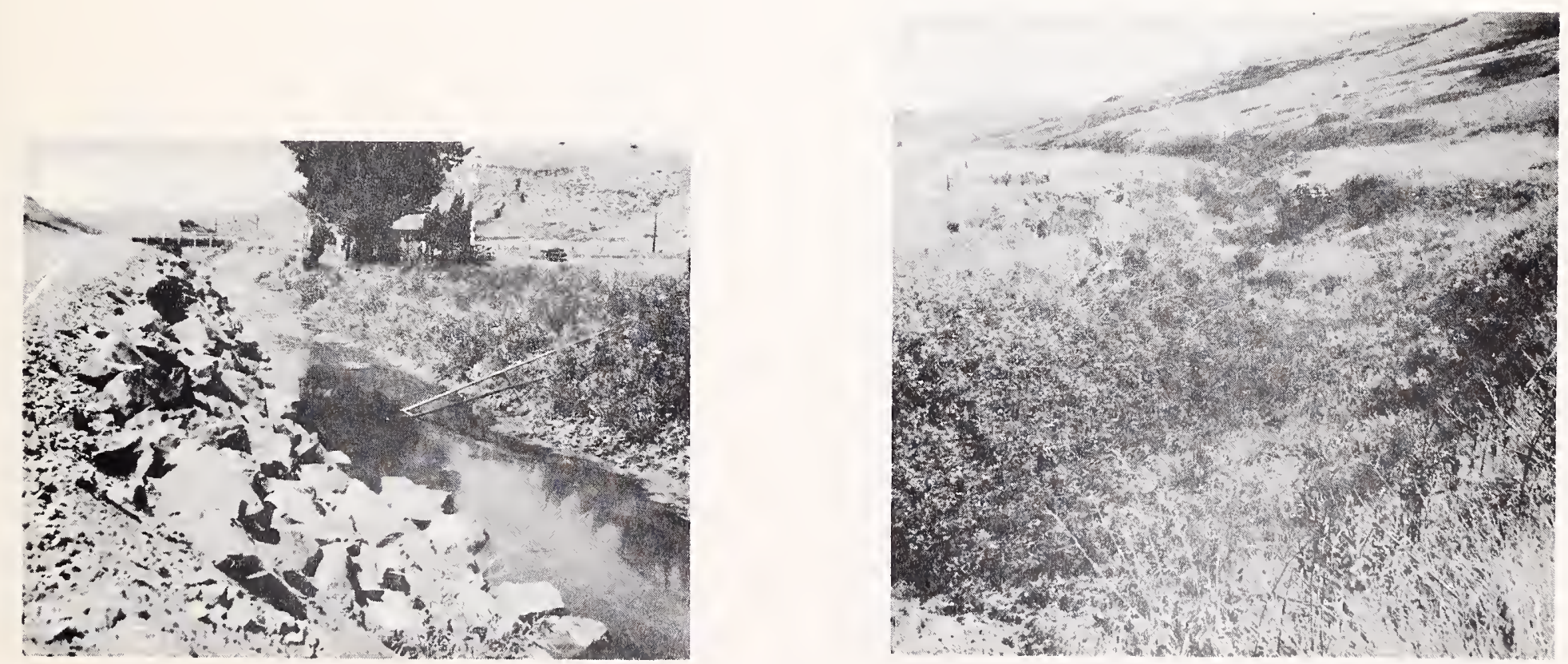

No. 27

No. 28

Channel alterations from Otter Creek near Raynesford, Montana. Nos. 25 and 27 show typical new channels that replaced natural stream channels, examples of which are shown in Nos. 26 and 28. 



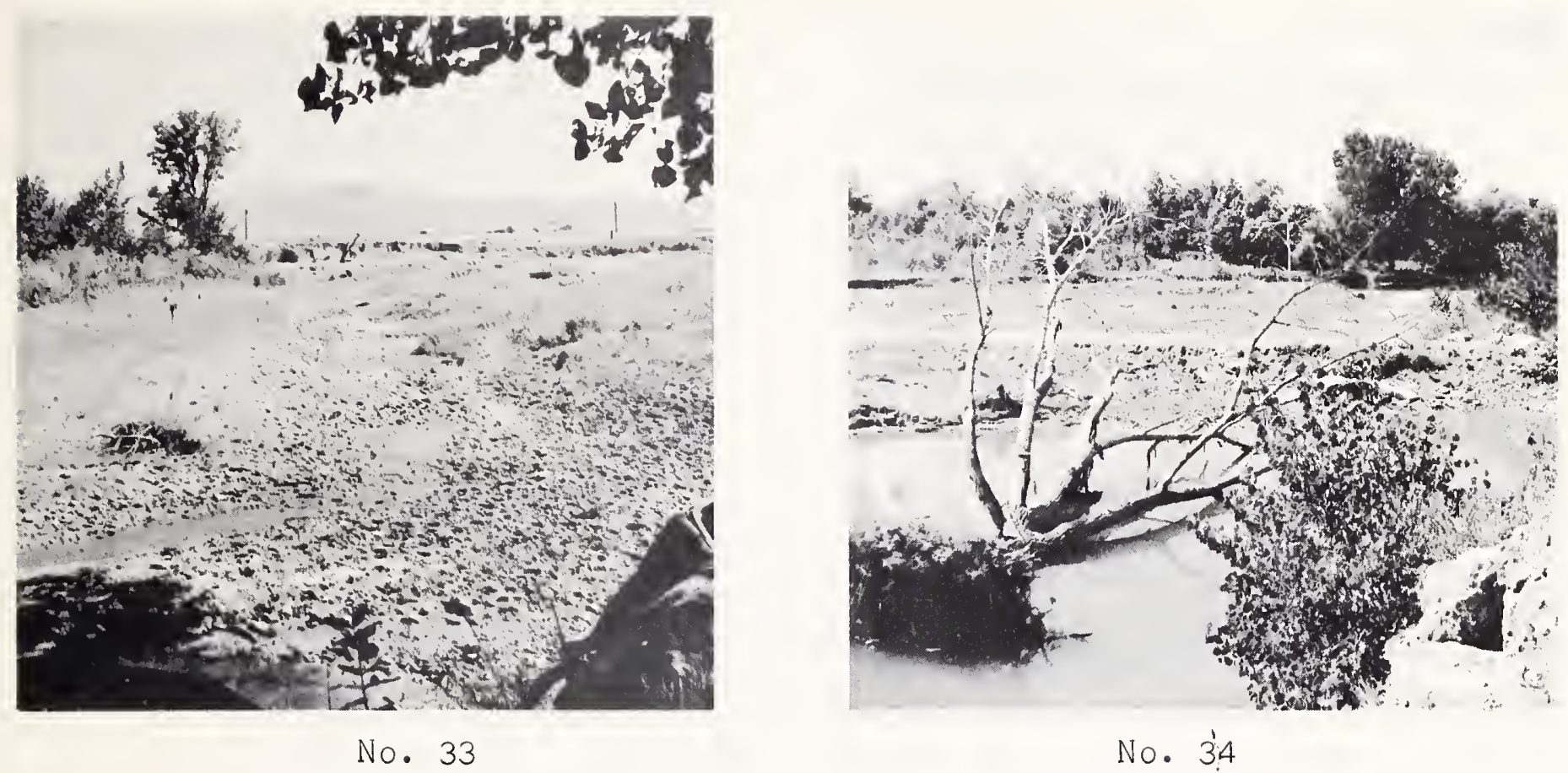

No. 34

Natural channels cut off by highway construction on Little Big Horn River. Note in No. 34 dike across river and note position of old creek channel.

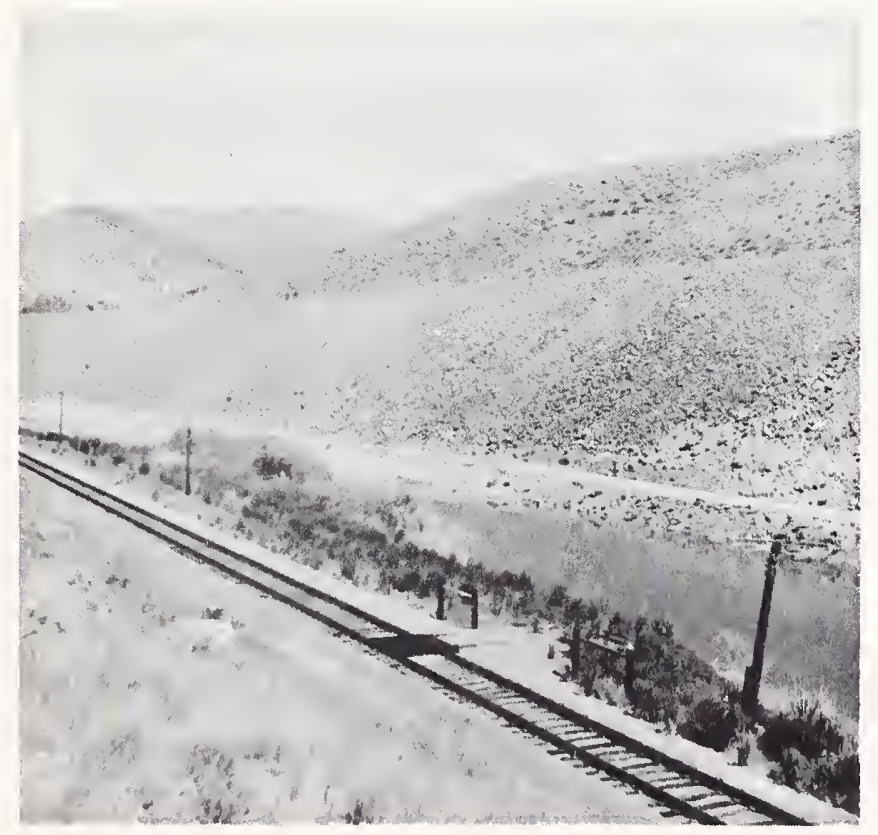

No. 35

Channel alteration on Beaverhead River near Armstead. 

<smiles>CC[SiH3]</smiles> 